\title{
Indoor Air Quality Assessment of Federal University Dutse Library North West, Nigeria
}

\section{1*ADELEYE, AO; ${ }^{1}$ AMOO, AO; ${ }^{1}$ OMOKHUDU, GI; ${ }^{1,2}$ HASSAN, A; ${ }^{3}$ OLATOMIWA, OJ; ${ }^{1}$ ZAKARIYYA, MK}

\author{
${ }^{1 *}$ Department of Environmental Sciences, Faculty of Science, Federal University Dutse, Nigeria \\ ${ }^{2}$ Department of Public Health, Ministry of Health Jigawa State, Nigeria. \\ ${ }^{3}$ Department of Microbiology and Biotechnology, Faculty of Science, Federal University Dutse, Nigeria \\ *Corresponding author email: adeniyi.adeleye@fud.edu.ng; adeniyiadeleye80@ gmail.com \\ Telephone: +2348162784457
}

\begin{abstract}
The present study was aimed at evaluating the number of bacteria and fungi in the indoor environment of Federal University Dutse Library. The sampling site was located in the University main reading room. Forty (40) air samples were collected in the month of June 2018. Air samples comprising of twenty (20) for bacteria and twenty (20) for fungi were taken twice a day; in the morning and afternoon. All the samples were analyzed for the concentration of bacteria and fungi using plate count method. The average bacterial and fungal counts in the library were found to be 240.10 $\mathrm{CFU} / \mathrm{m} 3$ and $280.60 \mathrm{CFU} / \mathrm{m} 3$ respectively and ranged from $132-345 \mathrm{CFU} / \mathrm{m} 3$ for bacteria and $180-416 \mathrm{CFU} / \mathrm{m} 3$ for fungi respectively. Having subjected the generated results to statistical analysis (T-test at 95\% confidence limit), there was no significant difference between microbial loads recorded for bacteria and fungi ( $p$-value $=0.000$ ). However, the mean microbial concentration of the library indoor air was within a range which indicates intermediate level of contamination according to the guidelines established in 1993 by the European Community Commission. It is therefore recommended that the surfaces of the library should be kept clean and dry, as the wet condition in the library can cause growth of pathogenic microorganisms. Again, a follow up study is required with a view to detecting seasonal variations of the indoor microbial counts of the library.
\end{abstract}

\section{DOI: https://dx.doi.org/10.4314/jasem.v22i10.16}

Copyright: Copyright $\odot 2018$ Adeleye et al. This is an open access article distributed under the Creative Commons Attribution License (CCL), which permits unrestricted use, distribution, and reproduction in any medium, provided the original work is properly cited.

Dates: Received: 10 September 2018; Revised: 12 October 2018; Accepted: 29 October 2018

Keywords: Indoor air quality, pollution, bacterial counts, fungal counts

Indoor air quality (IAQ) connotes the air parameters that are found inside buildings, businesses, schools, and homes. The source of contamination can differ from biological resources or chemical resources (EPA, 1995). Air is an invisible gas that is made up of a mixture of mainly Nitrogen and Oxygen. It is one of the fundamental basics of life for humans, animals and plants. The quality of the air that we breathe in goes a long way in determining our health status. Quarcoo et al. (2012), reported that it is becoming increasingly important to keep it clean for the future. Environmental air does contain a compound mixture of toxics, including particulate matter (PM), irritant gases, and benzene (Lodovici and Bigagli, 2011). It has been established that IAQ is one of the most significant factors that influences our general life quality as we breathe $10 \mathrm{~m}^{3}$ air every day, and we spend $80-95 \%$ of our lives indoors. According to Cabral (2010), indoor air pollution can result in health problems and even an increase in human mortality. Indoor environments contain a complex mixture of live and dead microorganisms, fragments, toxins, allergens, volatile microbial organic compounds and other chemicals (WHO, 2009). According to Maeir et al. (2002), specific activities like talking, sneezing, coughing, walking, washing and toilet flushing can readily generate airborne biological particulate matter. Therefore, the task of microbial inspections is to distinguish between normal indoor microorganisms, airborne or adherent to walls and floors and fastgrowing species, attaching itself to building materials and producing microbial products and eventually triggering antagonistic health effects (Madukasi et al., 2010). Hence, the objective of this paper is to present the microbiological quality of the indoor air of Federal University Dutse library.

\section{MATERIALS AND METHODS}

Sampling site: Air sampling was done in the building of the University Library, which is a part of the building complex of the Federal University Dutse permanent site, located at Ibrahim Aliyu bye-pass in 
Dutse metropolis North West, Nigeria. Since it opened in 2016, the University Library has gathered a vast collection of books and magazines as well as special collections of manuscripts, graphics, and documents on social life.

Sampling: Air sampling was conducted at daily intervals for two weeks, twice a day - early in the morning before the library staff start working in order to determine indoor background, and in the afternoon when the highest number of students and academic teachers use the library collections the most as done by Kalwasińska et al., (2012).

Study Duration: Cross-sectional study was conducted in the month of June 2018 to assess bacterial and fungal counts in the indoor air of the library.

Sample size: Forty (40) air samples were collected randomly from the library as done by Kalwasińska $e t$ al., 2012.

Method: Air sampling was done using plate methods. Petri dishes containing nutrient agar and sabouraud dextrose agar were transported to Federal University Dutse library in sealed plastic bags as done by Kalwasińska et al. (2012). A sensitive weighing balance machine was used to measure the amounts of the nutrient agar and sabouraud dextrose agar required for the analysis. The culture media were dissolved and prepared according to manufacturers' instructions. The plates were labelled with sample number and time of collection. The plates were placed at main reading section in the library at about one (1) meter above the ground representing human breathing zone. All the plates were exposed for ten (10) minutes. After this exposure, the plates were covered and taken to the laboratory in sealed plastic bags for incubation and subsequent enumeration. The results were expressed as colony forming units in a cubic metre of air $\left(\mathrm{CFU} / \mathrm{m}^{3}\right)$ as averred by Kalwasińska et al. (2012).

Incubation and Enumeration: A. Total bacterial count (T.B.C): Nutrient agar plates (NA) used for the collection of the samples meant for bacterial counts were transferred to the laboratory in a bag and subsequently incubated for 24 hours at $37^{\circ} \mathrm{C}$ before using electric colony counter to count the colonies at the end of incubation period as done by Abed (2014).

Total fungal count: Sabouraud dextrose agar (SDA) was used for fungal counts. The plates were transferred to the laboratory in a bag and incubated for 24 hours at $25^{\circ} \mathrm{C}$ before using electric colony counter to count the colonies at the end of incubation period as done by Hayleeyesus and Manaye (2014).

Statistical analysis: IBM SPSS Statistics 19 software was applied to determine the likelihood of statistically significant differences (morning and afternoon) between the concentrations of bacteria and fungi measured in the indoor environment of the library as done by Kalwasińska et al. (2012).

\section{RESULTS AND DISCUSSION}

All the forty (40) samples collected in this current study yielded bacterial growth on nutrient agar and fungal growth on Sabouraud dextrose agar. Table 1 shows the bacterial and fungal loads in all the air samples collected in the library and subsequently subjected to microbial analysis. The results obtained indicate that the number of microorganisms (bacteria and fungi) in the indoor air of the library varied significantly in the morning and afternoon. From Table 1, the concentration of fungi in the indoor air can be seen to be higher than the concentration of bacteria considering total bacterial $\left(4802 \mathrm{CFU} / \mathrm{m}^{3}\right)$ and fungal $\left(5612 \mathrm{CFU} / \mathrm{m}^{3}\right)$ counts of all air samples analysed. Furthermore, the microbial loads recorded in the morning were lower than the loads recorded in the afternoon in most cases as against the findings of Kalwasinska et al. (2012). Furthermore, the mean bacterial and fungal loads in the library were found to be $240.10 \mathrm{CFU} / \mathrm{m}^{3}$ and $280.60 \mathrm{CFU} / \mathrm{m}^{3}$ for bacteria and fungi respectively.

Exposure to bio-aerosols has become a significant public health concern. Currently, there is not a precise legislation in Nigeria on the microbiological quality of the air. In this context, the European Community Commission (ECC) (1993) which has proposed five different categories to evaluate the level of microbial contamination in the indoor air of non-industrial environments is adopted for comparison in this current study. From Table 2, apart from the overall mean value $\left(240.0 \mathrm{cfu} / \mathrm{cm}^{3}\right)$, it can be deduced that bacteria had a minimum value $\left(132.0 \mathrm{cfu} / \mathrm{cm}^{3}\right)$, maximum value $\left(345.0 \mathrm{cfu} / \mathrm{cm}^{3}\right)$ with range of $132-345 \mathrm{cfu} / \mathrm{cm}^{3}$. Fungi were also enumerated, in which the minimum value $\left(180.0 \mathrm{cfu} / \mathrm{cm}^{3}\right)$ and the maximum value $\left(416.0 \mathrm{cfu} / \mathrm{cm}^{3}\right)$ were recorded with a range $(180-416$ $\left.\mathrm{cfu} / \mathrm{cm}^{3}\right)$ and mean value $\left(280.600 \mathrm{cfu} / \mathrm{cm}^{3}\right)$ respectively. Consequently, going by the ECC standard and grouping, the indoor air of the Federal University Dutse library, as a whole, shows an intermediate level of microbial contamination as contamination levels of bacteria and fungi recorded in the library fall in the range of the recommended microbial counts $\left(<500 \mathrm{CFU} / \mathrm{m}^{3}\right)$, as against the earlier findings of Abed (2014). 
Table 1: Number of days, time of samples' collection as well as bacterial and fungal counts respectively.

\begin{tabular}{cccc}
\hline $\begin{array}{c}\text { Number } \\
\text { of days }\end{array}$ & $\begin{array}{c}\text { Time of samples } \\
\text { collection }\end{array}$ & $\begin{array}{c}\text { Bacterial } \\
\text { counts }\left(\mathbf{c f u} / \mathbf{m}^{3}\right)\end{array}$ & $\begin{array}{c}\text { Fungal counts } \\
\left(\mathbf{c f u} / \mathbf{m}^{3}\right)\end{array}$ \\
\hline 1 & Morning & $1.92 \times 10^{2}$ & $2.02 \times 10^{2}$ \\
& Afternoon & $2.13 \times 10^{2}$ & $2.44 \times 10^{2}$ \\
2 & Morning & $1.81 \times 10^{2}$ & $1.85 \times 10^{2}$ \\
& Afternoon & $1.89 \times 10^{2}$ & $2.71 \times 10^{2}$ \\
3 & Morning & $2.12 \times 10^{2}$ & $2.49 \times 10^{2}$ \\
& Afternoon & $2.52 \times 10^{2}$ & $3.03 \times 10^{2}$ \\
4 & Morning & $1.32 \times 10^{2}$ & $1.99 \times 10^{2}$ \\
& Afternoon & $2.76 \times 10^{2}$ & $3.21 \times 10^{2}$ \\
5 & Morning & $2.43 \times 10^{2}$ & $1.80 \times 10^{2}$ \\
& Afternoon & $3.22 \times 10^{2}$ & $3.88 \times 10^{2}$ \\
6 & Morning & $2.92 \times 10^{2}$ & $2.01 \times 10^{2}$ \\
& Afternoon & $3.04 \times 10^{2}$ & $3.78 \times 10^{2}$ \\
7 & Morning & $2.61 \times 10^{2}$ & $2.66 \times 10^{2}$ \\
& Afternoon & $2.79 \times 10^{2}$ & $3.95 \times 10^{2}$ \\
8 & Morning & $1.87 \times 10^{2}$ & $1.94 \times 10^{2}$ \\
& Afternoon & $2.97 \times 10^{2}$ & $4.01 \times 10^{2}$ \\
9 & Morning & $2.02 \times 10^{2}$ & $2.03 \times 10^{2}$ \\
& Afternoon & $2.44 \times 10^{2}$ & $3.99 \times 10^{2}$ \\
10 & Morning & $1.79 \times 10^{2}$ & $2.17 \times 10^{2}$ \\
& Afternoon & $3.45 \times 10^{2}$ & $4.16 \times 10^{2}$ \\
& Total & 4802 & 5612 \\
& Mean & 240.100 & 280.600 \\
\hline
\end{tabular}

As depicted in Table 3 below, it can be deduced that bacterial count in the morning had minimum value $\left(132.0 \mathrm{CFU} / \mathrm{m}^{3}\right)$ and maximum value $\left(292.0 \mathrm{CFU} / \mathrm{m}^{3}\right)$ with range $\left(132-292 \mathrm{CFU} / \mathrm{m}^{3}\right)$ and also mean value $\left(208.100 \mathrm{CFU} / \mathrm{m}^{3}\right)$. In the afternoon, it had a minimum value $\left(189.0 \mathrm{CFU} / \mathrm{m}^{3}\right)$ and maximum value $(345.0$ $\left.\mathrm{CFU} / \mathrm{m}^{3}\right)$ with a range $\left(189-345 \mathrm{CFU} / \mathrm{m}^{3}\right)$ and also mean value $\left(208.100 \mathrm{CFU} / \mathrm{m}^{3}\right)$. From Table 3, it can be seen that the microbial load of bacteria enumerated in the morning had a minimum, maximum, range and mean value of $132.0 \mathrm{CFU} / \mathrm{m}^{3}, 292.0 \mathrm{CFU} / \mathrm{m}^{3}, 132-292$ $\mathrm{CFU} / \mathrm{m}^{3}$ and $208.100 \mathrm{CFU} / \mathrm{m}^{3}$ respectively. It can be said to be less than that of the afternoon with minimum value $\left(189.0 \mathrm{CFU} / \mathrm{m}^{3}\right)$, maximum value $(345.0$ $\left.\mathrm{CFU} / \mathrm{m}^{3}\right)$, range $\left(189-345 \mathrm{CFU} / \mathrm{m}^{3}\right)$ and mean value $\left(208.100 \mathrm{CFU} / \mathrm{m}^{3}\right)$. These results can be attributed to the fact that there were more activities carried out in the afternoon than in the morning in the library during the period of this study.

Table 2: Number of samples, minimum count, maximum count, mean, range $\mathrm{T}$ value and $\mathrm{p}$ value of bacterial and fungal concentrations

\begin{tabular}{llllllll}
\multicolumn{7}{c}{ respectively. } \\
\hline Organisms & N & Minimum & Maximum & Mean & Range & T value & p-value \\
\hline Bacteria & 20 & 132.0 & 345.0 & 240.100 & $132-345$ & 18.988 & 0.000 \\
Fungi & 20 & 180.0 & 416.0 & 280.600 & $180-416$ & 14.529 & 0.000 \\
\hline
\end{tabular}

Table 3: Number of samples, mean, minimum, maximum, range t-value and p-value of bacterial and fungal concentration in the morning

\begin{tabular}{lllll}
\hline \multicolumn{4}{c}{ and afternoon. } \\
\hline Time & Morning & Afternoon & Morning & Fungi \\
\hline $\mathrm{N}$ & 10 & 10 & 10 & Afternoon \\
Mean & 208.100 & 272.10 & 209.600 & 351.60 \\
Minimum & 132.0 & 189.0 & 180.0 & 244.0 \\
Maximum & 292.0 & 345.0 & 266.0 & 416.0 \\
Range & $132-292$ & $189-345$ & $180-266$ & $244-416$ \\
T value & 14.253 & 17.772 & 24.113 & 18.060 \\
Sig (p-value) & 0.000 & 0.000 & 0.000 & 0.000 \\
\hline
\end{tabular}

Fungal concentrations were also enumerated in the library across both periods (morning and afternoon). The minimum value $\left(180.0 \mathrm{CFU} / \mathrm{cm}^{3}\right)$ and maximum value $\left(266.0 \mathrm{cfu} / \mathrm{cm}^{3}\right)$ were recorded with a range $\left(180-266 \mathrm{cfu} / \mathrm{cm}^{3}\right)$ and a mean value (209.600 $\mathrm{cfu} / \mathrm{cm}^{3}$ ) in the morning. In the afternoon, the minimum value $\left(244.0 \mathrm{CFU} / \mathrm{m}^{3}\right)$ and maximum value $\left(416.0 \mathrm{CFU} / \mathrm{m}^{3}\right)$ were recorded with a range (244-416 $\left.\mathrm{CFU} / \mathrm{m}^{3}\right)$ and also a mean value $\left(351.60 \mathrm{CFU} / \mathrm{m}^{3}\right)$. It can also be deduced that the microbial load of the enumerated fungi in the afternoon with minimum, maximum, range and mean value of $244.0 \mathrm{CFU} / \mathrm{m}^{3}$, 416.0 CFU $/ \mathrm{m}^{3}, 244-416 \mathrm{CFU} / \mathrm{m}^{3}$ and $351.60 \mathrm{CFU} / \mathrm{m}^{3}$ respectively, can be seen to be greater than the loads recorded in the morning with minimum, maximum, range and mean value of $180.0 \mathrm{CFU} / \mathrm{m}^{3}, 266.0$ $\mathrm{CFU} / \mathrm{m}^{3}, 180-266 \mathrm{CFU} / \mathrm{m}^{3}$ and $209.600 \mathrm{CFU} / \mathrm{m}^{3}$ respectively. These can be attributed to the activities going on in the library such as coughing, sneezing, talking, irregular and infrequent cleaning at the periods of investigation. These factors have been established by Maeir et al., (2002) as predominant sources of indoor contamination of air caused by bacteria and fungi. These new findings corroborate the earlier findings of Toivola (2004); Fox et al. (2005) Jo and Seo (2005). However, as depicted in Table 3, there is no statistically significant difference between microbial loads recorded for bacteria and fungi considering the $\mathrm{p}$-value $=0.000$ as against the earlier findings of Eman (2014). Based on permissible standard, the library microbial load is considered to be intermediate contamination as prescribed by ECC (1993).

Conclusion: In this current study, it can be concluded that the total number of bacteria and fungi growing 
from the air samples taken in the afternoon recorded in most cases higher values in comparison with the bacteria and fungi growing from the samples taken in the morning. This may be due to increased number of students and human activities like coughing, sneezing, talking, irregular and infrequent cleaning at the periods of investigation. Based on the results and findings of this current research, it is therefore recommended that periodic monitoring of indoor microbial quality of the library should be routinely done. Again, it is appropriate to use natural ventilation provided through open windows and doors instead of mechanical ventilation in the library. There is equally a need to create educational programmes with a view to increasing awareness amongst the users of and workers in the library about the detrimental effects of microbial indoor pollution. Water pipelines in the library need to be checked regularly and replaced when damaged, because any wet condition can cause growth of pathogenic microorganisms and inevitably spread such across. A follow up study should be conducted with a view to detecting seasonal variations of microbial loads coupled with a further study to identify bacterial and fungal isolates from outdoor air environment of the library.

Acknowledgement: We are grateful to the management of the General Hospital Dutse North West Nigeria and the entire staff of the Microbiology Laboratory for affording us the opportunity of staging the bench work of this study therein.

\section{REFERENCES}

Abed, EY (2014). Assessment of Indoor Microbial Quality of Science Laboratories at Three Universities in Gaza City. A Thesis Submitted in Partial Fulfillment of the Requirement for the Degree of Master of Science in Environmental Sciences The Islamic University - Gaza - Palestine. Available http://library.iugaza.edu.ps/thesis/114758.pdf. (Retrieved on 12th August, 2018).

Cabral, J (2010). Can we use indoor fungi as bio indicators of indoor air quality? Historical Perspectives and Open Questions. Sci of the total envt. 408: $4285-4295$.

European Communities Commission (ECC) (1993). Indoor Air Quality and Its Impact on Man. Report No. 12 Biological Particles in Indoor Environments. Available on http://www.inive.org/medias/ECA/ECA_Report12. pdf. (Retrieved on 6th October, 2018).
Environmental Protection Agency (EPA) (1995). Indoor air pollution. A self-placed learning module. (EPA 402-K- 95-001). Washington, DC: USA.

Fox, A; Harley, W; Feigley, C; Salzberg, C; Toole, C; Sebastian, A; Larsson, L (2005). Large Particles are Responsible for elevated Bacterial Marker Levels in School Air upon Occupation. Journal of Environmental Monitoring 7: 450-456.

Hayleeyesus, SF; Manaye, AM (2014). Microbiological Quality of Indoor Air in University Libraries. Asian Pacific Journal of Tropical Biomedicine 4(Suppl 1): 312-317.

Jo, WK; Seo, .J (2005). Indoor and Outdoor Bioaerosol Levels at Recreation Facilities, Elementary Schools, and Homes. Chemosphere. 61: 1570-1579.

Kalwasińska, A; Burkowska, A; Wilk, I (2012). Microbial Air Contamination in Indoor Environment in the University. Annals of Agricultural and Environmental Medicine. 19 (1): 25-29.

Lodovici, M; Bigagli E (2011). Oxidative Stress and Air Pollution Exposure. Journal of Toxicology, ID 487074 http://dx.doi.org/10.1155/2011/487074

Madukasi, EI; Dai, X; He, C; Zhou, J (2010). Potentials of Phototrophic Bacteria in Treating Pharmaceutical Wastewater. Int. J. Environ. Sci. Tech. 7 (1): 165174.

Maeir, RM.; Pepper, JL.; Gerba, PC (2002). Environmental Microbiology 2nd Edition. Canada, Academic Press.

Quarcoo S; Kwame J; Ofosu F; Aboh I (2012). Particulate Matter and Black Carbon Concentration Levels in Ashaiman. Research Journal of Environmental and Earth Sciences. 4: 20-25.

Toivola, M (2004). Personal Exposure to Microbial Aerosols. Available at http://epublications.uef.fi/pub/urn_isbn_951-740461-1/urn_isbn_951-740-461-1.pdf. (Retrieved on 6th October, 2018).

World Health Organization (WHO) (2009). WHO Guidelines for Indoor Air Quality -Dampness and Mould. Available at http://www.who.int/airpollution/guidelines/dampne ss-mould/en/. (Retrieved on 6th October, 2018). 